\title{
COINCIDENCE PROBLEMS UNDER CONTRACTIVE TYPE CONDITIONS
}

\author{
J. GARCIA-FALSET* ${ }^{*}$ O. MUÑIZ-PÉREZ** AND K. SADARANGANI*** \\ * Departament d'Anàlisi Matemàtica, Universitat de València \\ Dr. Moliner 50, 46100, Burjassot, València, Spain \\ E-mail: garciaf@uv.es \\ ** Departament d'Anàlisi Matemàtica, Universitat de València \\ Dr. Moliner 50, 46100, Burjassot, València, Spain \\ E-mail: omar.muniz@uv.es \\ *** Departamento de Matemáticas, Universidad de Las Palmas de Gran Canaria \\ Campus de Tafira Baja 35017, Las Palmas de Gran Canaria, Spain \\ E-mail: ksadaran@dma.ulpgc.es
}

Abstract. The main purpose of this paper is to establish some new results about the existence and uniqueness for coincidence problems for two single-valued mappings. Moreover, we present some applications of our results to the existence and uniqueness of solutions of some boundary value problems.

Key Words and Phrases: Coincidence problem, altering distance function, comparison function, $\phi$-contraction, differential equation.

2010 Mathematics Subject Classification: 47H09, 54H25, 34B15, 47H10.

Acknowledgement. The research of the first author has been partially supported by a Grant MTM2012-34847-C02-02 from Ministerio de Economía y Competitividad (Spain). The second author has been partially supported by CONACyT (Mexico). The third author is partially supported by the project MTM2013-44357 - P.

\section{REFERENCES}

[1] D.W. Boyd, J.S.W. Wong, On nonlinear contractions, Proc. Amer. Math. Soc., 20(1969), 458464.

[2] A. Buică, Principii de coincidenţă şi aplicaţii, Presa Universitară Clujeană, Cluj-Napoca, 2001.

[3] N. Cakić, Coincidence and common fixed point theorems for $(\varphi, \phi)$ weakly contractive mappings in generalized metric spaces, Filomat, 27(2013), no. 8, 1415-1423

[4] L.B. Ciric, Generalized contractions and fixed point theorems, Publ. Inst. Math., Beograd, 12(1971), 19-26.

[5] P.N. Dutta, B.S. Choudhury, A generalisation of contraction principle in metric spaces, Fixed Point Theory Appl., 2008, Art. ID 406368, 8 pages, doi:10.1155/2008/406368.

[6] J. Garcia-Falset, O. Mleşniţe, Coincidence problems for generalized contractions, Appl. Anal. Discrete Math., 8(2014), 1-15.

[7] K. Goebel, A coincidence theorem, Bull. Acad. Polon. Sci. Sér. Sci. Math. Astronom. Phys., 16(1968), 733-735. 
[8] W.A. Kirk, B. Sims (Eds.), Handbook of Metric Fixed Point Theory, Kluwer Academic Publishers, Dordrecht, Boston, London, 2001.

[9] O. Mleşniţe, Contributions to the study of the coincidence point problem for singlevalued and multivalued operators, PhD. Thesis, Babeş-Bolyai University Cluj-Napoca, 2013.

[10] B.E. Rhoades, Some theorems on weakly contractive maps, Nonlinear Anal., 47(2001), 26832693.

[11] I.A. Rus, Generalized Contractions and Applications, Cluj University Press, Cluj-Napoca, 2001.

[12] T. Suzuki, A generalized Banach contraction principle that characterizes metric completeness, Proc. Amer. Math. Soc., 136(2008), 1861-1869.

Received: May 14, 2014; Accepted: August 26, 2014. 